DOI: 10.47745/ERJOG.2020.02.06

\title{
ÁBRAHÁM BARNA
}

\section{A nemzetiségi törvény szlovák szemmel}

\section{The Act on National Minorities in the Eyes of Slovakians}

Abstract: As a starting point, the study underlines that one cannot speak about a homogenous Slovak nation and politics in the middle of the $19^{\text {th }}$ century; therefore, it gives an overview of the plebeian-middle-class movement, of its system of values, programme, and documents in 1848-1849, 1861, and in the period of the Compromise negotiations. Afterwards, it presents the nobility of Upper Hungary, with a Slovak mother tongue and ethnic feeling, who, according to its identity in the framework of the states, has belonged to the feudal Natio Hungarica. As the narrower focus of the study, the author takes the Slovak perspective and summarizes the ethnic dimensions of the activity of parliaments in 1861 and from 1865 on. The Slovak national movement could not send its own deputy, the interests of the Slavs of northern Hungary thus being represented by Adolf Dobriansky, born as a Ruthenian; however, the Nationalities Law, Art. 1868: XLIV. could be codified rather due to the mentioned Slovak-speaking nobility, standing behind the party of Ferenc Deák. Finally, we are provided a picture of the rival programmes of different newspapers that divided the Slovak public opinion, and in connection with the law we can read about their first reactions and experiences.

Keywords: Slovak national movement, Slovak demands on autonomy, Slovak politics in 1848-1849, Slovak Memorandum (1861), Slovak perception of art. 1868: XLIV.

Összefogaló: A tanulmány kiindulópontja, hogy a XIX. század derekán nem beszélhetünk egységes szlovák nemzetről és politikáról, ezért áttekinti a plebejus-polgári hátterű nemzeti mozgalom értékrendjét, programját és dokumentumait 1848-1849-ben, 1861-ben és a kiegyezési tárgyalások során. Ezt követi a szlovák ajkú és etnikai tudatú, de rendi identitása szerint a feudális Natio Hungarica részét alkotó felföldi nemesség bemutatása. Szűkebb tárgyaként szlovák szempontból vázolja az 1861-es és az 1865-ben összeült országgyűlés nemzetiségi vonatkozásait. A szlovák nemzeti mozgalom nem tudott képviselőt bejuttatni, a ruszin Dobrjánszky Adolf vállalta az észak-magyarországi szlávok képviseletét, az 1868. évi XLIV. törvény megszületése viszont sokkal inkább az említett, a Deák-párt mögött álló szlovák ajkú nemességnek köszönhető. Végül képet kapunk a szlovák közéletet megosztó folyóiratok konkurrens programjairól és a törvényt illető reakcióiról, tapasztalatairól.

Kulcsszavak: szlovák nemzeti mozgalom, szlovák autonómiatörekvések, szlovák politika 1848-1849-ben, szlovák Memorandum (1861), az 1868. évi XLIV. tc. szlovák megítélése.

" A tanulmány a Contrasting Romanian and Hungarian histories (on the anatomy of the great debats) címü, 128151. sz. nemzetközi OTKA-pályázat keretében készült. 


\section{Bevezetö}

Jelen tanulmány szerzőjének elsődleges kötelessége, hogy előrebocsássa: a cím hagyományos kategóriáink szerint aligha értelmezhető. Egyrészt - és ez talán a kisebbik probléma - az ő szemükkel nézve az 1868: XLIV. tc. nem az, amit elnevezése vall, nem a „nemzetiségi egyenjogúságot” hirdeti meg és kodifikálja, hanem csupán nyelvtörvény, mely megengedi - mi hangsúlyozzuk: nagyvonalúan -, hogy bizonyos területeken használható az anyanyelv. A történész előtt tornyosuló nagyobbik kihívás az, hogy a XIX. század derekán nem mondható meg egyértelműen, ki a szlovák, pontosabban: mi a szlovák, azaz kikből áll, sőt létezik-e egyáltalán szlovák nemzet.

Fáradalmas, de megkerülhetetlen feladatunk tehát, hogy vázoljuk, mely tényezők hogyan képviselték a valós és vélt szlovák érdekeket, hogyan szolgálták a nemzetépítés ügyét. Külön kell tárgyalnunk - és még azt is kétfelé bontva - a polgári állású, modern nemzettudat által vezérelt csoportot, a rendiségben iskolázott, premodern hungarus identitású, de a magyarosítást - még - elfogadni nem képes szlovák ajkú felföldi nemességet, és a szlovák voltát hangsúlyozó, de a magyar nyelv térnyerését elfogadó lojális erőket.

\section{A plebejus nemzeti mozgalom igényei és eredményei 1848 márciusától az 1865-ös választásokig}

Ha ezt halljuk: ,a szlovákok”, akkor a mai nemzetükben gondolkodó és a magyarosítással, sőt a magyarsággal szemben álló személyekre gondolunk, aligha véletlenül, hiszen ezt szentesítette és élteti máig saját önképük, a szlovák történetírás és a mindenkori szlovák államrezon. ${ }^{1}$ A nemzeti mozgalom (maroknyi és megosztott) csapata az 1830as évektől általánosságban, hegeli alapon hirdette: minden nemzet a világszellem öntudatosodásának nélkülözhetetlen láncszeme, konkrétan pedig: a szlovákság nem csak őslakosa Hungáriának (melyet nyelvükön ugyanígy - Uhorsko - jelöltek), hanem

1 Vladimír Mináč író klasszikus tétele: „A magyarság a szlovák politika végzete. [...] Mozgásiránya a magyar politika mozgásirányának a negatívja, koncepciói ellenkoncepciók, hangja visszhang csupán." Nemzet él itt [1965]. In: Mináč Vladimír: Összefüggések, Madách Könyvkiadó, Bratislava, 1980, 86. A szlovák gondolkodás magyarságképét érzékelteti: Magyarságkép a XIX-XX. századi szlovák irodalomban (szemelvénygyüjtemény), összeállította és a bevezetőt írta: ÁBRAHÁm Barna, Magyar Napló 2006/18, 11, 41-68. A magyarországi nemzetiségpolitika és nemzetiségi törekvések e korszakbeli forrásait közli: KEMÉNY G. Gábor: Iratok a nemzetiségi kérdés történetéhez Magyarországon a dualizmus korában I, Tankönyvkiadó, Budapest, 1952, http://adatbank.transindex.ro/cedula. php?kod=1049.; KemÉny G. Gábor: A szomszéd népekkel való kapcsolataink történetéböl. Válogatás hét évszázad írásaiból, Tankönyvkiadó, Budapest, 1962.; BALoGH Sándor (föszerk.), Sipos Levente (szerk.): A magyar állam és a nemzetiségek. A magyarországi nemzetiségi kérdés történetének jogforrásai 1848-1993, Napvilág Kiadó, Budapest, 2002. Átfogó feldolgozása: KemÉny G. Gábor: A nemzetiségi kérdés története. I. A nemzetiségi kérdés a törvények és tervezetek tükrében 1790-1918, Budapest, 1947. 
a roppant szláv nemzet központja, és fejlett IX. századi, nagymorva államiságának köszönhetően a barbár magyarok tanítójává válhatott.

1848 tavaszán érzékelték, hogy az áprilisi törvények az általános jogegyenlőség kimondásán túl nem adják meg a nem magyar népeknek a nemzeti fejlődés lehetőségét. A liptóiak már a forradalom után követelték, „hogy szlovák nemzetiségünk joga, amelyről nem akarunk lemondani, és nem is szabad lemondanunk, a politikai és társadalmi életben számunkra szentül biztositva legyen és örök időkre sértetlenül és érintetlenül megmaradjon", követelve a szlovák elsődleges használatát a közigazgatásban, igazságszolgáltatásban és az oktatásban. ${ }^{2}$

Konkrétabban fogalmazott a breznóbányaiak májusi petíciója (középfokon és a tanítóképzőkben is szlovák tannyelv, a magyar pedig tantárgy legyen), ${ }^{3}$ majd május 10-én a nemzeti mozgalom vezetői (L'udovít Štúr, Jozef Miloslav Hurban, Michal Miloslav Hodža) Liptószentmiklóson meghirdették A Szlovák Nemzet Kivánságait. Határozottan üzente: „A magyarországi hazában élő szlovák nemzet kilencszáz esztendős álom után magát az ország ösi nemzetének érzi, és annak tudatára ébred, hogy ez a szent föld és anyaország, ahonnan származik, és amely ôsei régi dicsőségét elbeszélő bölcsője és az a szintér, amelyen atyái és hősei vérüket ontották a magyarországi koronáért, a legutóbbi időkig csak mostohája volt, amely irgalmatlanul bánt véle és nyelvét és nemzetiségét a szégyen és gyalázkodás bilincseiben tartotta." ${ }^{4}$

A petíció szempontunkból legfontosabb pontjai:

- a magyarországi nemzetek általános országgyủlésében a képviselők kötelesek nemzetük nyelvét használni és a többi képviselt nemzet nyelvét ismerni (!?);

- külön nemzeti gyủlések, ennek megvalósításához néprajzi határokat kell kijelölni, „hogy minden nemzet erösen vonzódhassék és jogosult legyen vonzódni nemzeti központjához, és hogy se a magyar kisebbség ne legyen kénytelen a szlovák többségnek, se a szlovák kisebbség a magyar többségnek szolgálni és magát alávetni";

- módosítandó az a törvény (1848. évi XVI. tc., e), mely szerint „a köztanácskozási nyelv mind a gyüléseken, mind a bizottmányokban Magyarországra nézve egyedül magyar", 5 amivel "nemzetünket mintegy törvénnyel kényszeritik törvénytelenségre”, helyette vezessék be az anyanyelvet!

- teljes nemzeti, szlovák tannyelvủ iskolarendszer - elemi, polgári reáliskolák, leánynevelők, tanítóképzők, papneveldék, gimnáziumok, líceumok, akadémiák, végül saját műszaki főiskola és egyetem;

- saját nemzeti színek (piros-fehér) használata;

- náluk a nemzetőrséget szlovákok vezessék szlovák vezényleti nyelvvel.

Mivel a forradalmi kormányzat a petíciót nem tárgyalta, sőt elfogatóparancsot adott ki a vezetők ellen, Štúrék Prágába mentek, és kezdeményezőként részt vettek a birodalom szlávjait képviselő Szláv Kongresszus megszervezésében. Itt a csehek

2 A szlovák nemzeti mozgalom Liptó megyei híveinek a megyegyủléshez intézett petíciója. Közli: SpIRA György: A nemzetiségi kérdés a negyvennyolcas forradalom Magyarországán, Kossuth Könyvkiadó, Budapest, 1980, 152-153.

3 Uo., 162.

4 Teljes szövege: Uo., 163-164.

5 https://net.jogtar.hu/ezer-ev-torveny?docid=84800016.TV 
olyan föderációs tervet ismertettek, mely egy tartományban egyesítette volna a cseh és a szlovák (valamint a lengyel és az ukrán) területeket. Štúrék viszont ezt a keretet legalább olyan veszélyesnek láthatták (az utóbbi fél évtized a cseh nemzeti mozgalommal folytatott nyelvi vitákkal, kölcsönös vádaskodással telt), mint Pest elutasító álláspontját, s kijelentették, hogy „a szlovákok problémáikat nem Magyarországtól elszakadva és a csehekkel egyesülve, hanem a jövőben is a magyar államkötelék keretei között

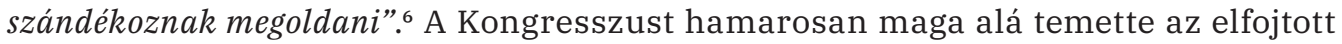
prágai fölkelés, a csehek vezetője, František Palacký azonban a birodalmi gyűlés számára 1849 januárjában kidolgozott alkotmánytervében újfent egy kiterjesztett cseh tartománycsoporttal számolt: Csehország, Morvaország és Szilézia cseh lakta része, valamint egész „Szlovákia”.

A szlovák vezetők még az előző ősszel megszervezték Bécsben a Szlovák Nemzeti Tanácsot (Slovenská národná rada) és a Szlovák Légiót, mely átlépte a határt. A szeptember 19-i miavai gyủlésen Štúr kikiáltotta Szlovákia önállóságát Magyarhon keretén belül, és megkezdődött az autonóm közigazgatás szervezése. A fölkelés azonban elszigetelt maradt, a morva határ menti szűk térre korlátozódott. A téli hadjárat, immár a császári hadsereg kötelékében, jelentősebb középszlovák területre hatolt be, és Jozef Miloslav Hurban immár Szlovákia Magyarhonból való kihasítását követelte (gr. Stadion belügyminiszter január eleji terve is önálló szlovák közigazgatási egységgel számolt). A vezetők kérvényt fogalmaztak a császárnak, melyben Szlovák Nagyfejedelemség néven önálló koronatartomány megszervezését kérték, ám a március 4-i oktrojált alkotmány kihirdetése után ez időszerűtlenné vált. Átdolgozott formában március 20-án nyújtotta át a delegáció Olmützben a Márciusi Folyamodványt, mely a szlovák nemzet odaadó hüségére és hadi érdemeire hivatkozva kérte „a majd három millió lelket számláló szlovák nemzetnek mint olyannak meghatározott országhatárokon belüli elismerését. Ezzel csak arra az országra utalunk, amelyet ősidők óta lakunk, amelyben a mi saját nyelvünk otthon van és a mindennapi életben egyedül használatos, amely hajdan a történelem színpadára történt fellépésünk bölcsője volt, s amely ha más területekkel együtt is alkot egy politikai egészet, ősidők óta sohasem vesztette el a szlovák föld, a Szlovákia (zem slovenská, Slovensko) nevet”. A „magyar nemzet uralmának visszatérésétôl megvédelmezett” Szlovákia az ausztriai monarchia egyenjogú tagjaként tarthasson évente tartományi országgyủlést, és saját, szlovák nyelvủ közigazgatása legyen. ${ }^{8}$ A kérvény sikertelen maradt, bár Világos után szlovák kormánymegbízottak kétszer újra benyújtották.

Az abszolutizmus időszaka semmiféle politikai szervezkedést nem tett lehetővé, ám a szlovák nemzetiek dokumentálhattak jótéteményeket Bécs részéről. Ferenc József besztercebányai püspökké nevezte ki a nyíltan szlovák öntudatú Štefan Moyzest, majd további két személyt emelt hasonló méltóságra. Moyzes erőfeszítései nyomán a német mellett csehül, illetve szlovákul kezdtek oktatni a besztercebányai katolikus állami gimnáziumban, 1862-ben pedig megnyílt a nagyrőcei evangélikus fö-, 1867-ben pedig

6 SPIRA: $i . m ., 58$.

7 Jan HavráneK: Nemzeti és birodalmi eszmények vonzásában. (František Palacký - a politikus és kora) = Csehország a Habsburg-monarchiában 1618-1918, szerk. SzARKa László, Gondolat Kiadó, Budapest, 1989, 120.

8 SPIRA: i. m., 206-207. 
A nemzetiségi törvény szlovák szemmel

a turócszentmártoni algimnázium (majd 1869-ben a hasonló katolikus znióváraljai intézmény), megszületett az oly régóta áhított anyanyelvi oktatási rendszer. 1863-ban össznemzeti kezdeményezésként, a megyei tisztikar tüntető részvételével, az uralkodótól érkező üdvözlettel és némi adománnyal Turócszentmártonban megalakult a nemzet közművelődési szervezete, a Matica slovenská.

A negyvennyolcas vezérkarból is többen jutottak pozícióba, a kisebb, szolgabírói pályák (Turócban Janko Jesenský Gašparé, Ďurka Toček) mellett kiemelendő: Ján Francisci-Rimavský előbb megyei megbízott lett Debrecenben, majd helytartósági tanácsos, végül egy évig Liptó megye főispánja. Štefan Marko Daxnert Gömör és Kis-Hont megye államügyészévé nevezték ki, később megyei törvényszéki bíró lett Nagykállóban, majd Gömör és Kis-Hont megye alispánja, végül a debreceni váltó-törvényszék rendes ülnöke.

A magyar történeti gondolkodásban sötét színű abszolutizmus évei társadalmi-kulturális szempontból tehát a szlovákság számára sikertörténet, maga a Provizórium pedig mint „a” liberalizmus időszaka fog rögzülni - szemben a kiegyezést követő „despotikus”, magyarosító fél évszázaddal.

Politikai föllépésre persze csak 1861-ben, az országgyủlési munkálatok idejében kerülhetett sor. A turócszentmártoni nemzetgyủlés június 7-én, éles belső viták után (több vezető személyiség elutasította az irreálisnak tekintett területi elkülönülést) elfogadta A Szlovák Nemzet Memorandumát. Az irat a szlovákok hangoztatott őslakos volta, egykori magas civilizációja és államisága alapján a magyar nyelv kiváltságolása előtti egyenlő helyzetet kívánta visszaállítani: „Úgy a csatatéren, valamint a közös törvényhozás terén is, minden nyelvkülönbség mellett igen jól megértették egymást a haza különböző népei, [...] egynek sem jutott eszébe másnak a nyelvét megvetni vagy éppen gyülölni, egyben sem támadt azon vágy, a maga növekvését másnak kiirtására fektetni, vagy a maga külön nemzeti érdekeit azon polcra tolni fel, melyen egyedül e haza valamennyi népeinek közös érdeke erösen és állandóan foglalhat helyt."

A Memorandum követelte, ,hogy hazánkban nemzeti egyediségünk (individualitásunk) s nemzeti nyelvünk mint honi nyelv [...] ármányok s megtámadtatások ellen biztositva legyen. [...] Mivel azonban minden, mi az anyagi világban létezik, csak bizonyos térben és időben létezhetik, ez oknálfogva: szükséges, hogy nemzetünk individualitása azon területen, melyet az mint egy szakadatlan tömeg valósággal elfoglal, egy, a megyék határainak nemzetiség szerinti kikerekitésével alakitandó felsö-magyarországi szláv kerületben (hornouhorské slovenské okolie) elösmerve s személyesitve legyen”. Az úgymond „legtisztább szláv megyék” (Trencsén, Árva, Turóc, Zólyom, Liptó, Szepes, Sáros) mellett a vegyes Pozsony, Nyitra, Bars, Hont, Nógrád, Gömör, Torna, Abaúj és Zemplén megyék szláv részei vagy új megyékké volnának alakíthatók, vagy északi szomszédjukhoz lennének csatolhatók. A „más nemzetbeliek” (nem a nemesek, mert azok a Memorandum szerint „elfajult” szlovákok, akik a korszellem hatására bizonyára visszatérnek „,a nemzet és a nép ölébe”) nemzeti különállást és jogokat nem igényelhetnek.

9 Teljes szövege: 1-ső melléklet a 133. sz. irományhoz = Az 1865-dikévi december 10-dikére hirdetett országgyülés képviselőházának irományai II., Pest, 1867, 251-257., idézett hely: 252. Összefoglalja: KeмÉny: A nemzetiségi kérdés... i. m., 65-68. 


\section{ERDÉLYI JOGÉLET}

A Memorandum fő nyelvi követelései:

- [a Kerületben] „a mi nyelvünk legyen egyedüli hivatalos nyelv, ugy a polgári, mint az egyházi nyilvános élet terén, segyedüli tanitási nyelv az iskolákban, mert azt hisszük, hogy nemzeti nyelvünk, mint nemzetünk szellemének valóságos kifejezése, mint nemzeti müvelödésünknek egyedüli eszköze s emeltyüje, az általunk lakott területen tehát, a maga lakában, nem lehet egy szorosabb körre, egy alárendelt szerepre utalva..."

- feljebbviteli és legalább egy váltótörvényszék szlovák hivatalos nyelvvel;

- az országos legfőbb semmisítő törvényszéknél és a közigazgatási legfőbb hatóságoknál szlovákul tudó és a nemzet igaz és hủ fiainak elismert előadók;

- a nemzeti szabadsággal és jogegyenlőséggel össze nem egyeztethető törvények (1791: XVI., 1792: VII., 1805: IV., 1836: III., 1840: VI., 1844: II., 1848: 5. §. 3. és 16. lit. E) eltörlése;

- szlovák jogakadémia;

- a pesti egyetemen szlovák nyelv és irodalom tanszék;

- irodalmi és erkölcsnevelő társulatok szabad alapítása.

Az országgyűlés nem tárgyalta a beadványt, sőt a megyei erők sokfelé tiltakozó akciókat szerveztek. A feloszlatás után a szlovák nemzeti vezetők közvetlenül Ferenc Józsefnek terjesztették elő, konkrétabb tartalommal: a kerületnek saját országgyủlést, törvényhozó és végrehajtó hatalmat igényeltek. A császár azonban a magyar uralkodó körökkel kereste a megegyezést, ezt nem kívánta radikális államjogi átszervezéssel nehezíteni.

Ami az országgyủlés terepét illeti, nemzeti elkötelezettségű szlovák nem jutott be a parlamentbe, a Sáros megyei, de ruszinnak tartott Dobrjánszky Adolfot tekintették az északi szlávok képviselőjének, ám ő sem jutott el addig, hogy előadhassa programját. ${ }^{10}$ Ennek lényege az alábbiakban foglalható össze:

- Az orosz [azaz ruszin] lakta területeken „akár egyedül, akár a szlovákokkal vegyesen, orosz vagy szlovák-orosz megyék létesittessenek”, teljes körü orosz ügyintézéssel.

- Az alispán, a szolgabíró és a tisztviselők oroszok legyenek, függetlenek a magyar uraktól. „Az orosz vagy orosz-szlovák megyék saját districtust alakitsanak”, orosz bírósággal, jogakadémiával, gimnáziummal.

- Évente nemzetgyủlés, egyházi és világi képviselőik megválasztása. Orosz metropólia és máramarosi orosz püspökség felállítása.

- Orosz képviselők minden vezető országos intézménynél. ${ }^{11}$

A röplapnak gyakorlati hatása az országgyủlés feloszlatása miatt természetesen nem lehetett.

10 A közismerten ruszofil Dobrjánszky a ruszin nemzeti gyủlésen anyanyelvű igazgatású megyéken alapuló, ruszin nemzetgyủlést is magában foglaló területi autonómia programját képviselte, amire a Kárpáti Hírnök így reagált: „Itt Ruthéniát vették tervbe, [...] némely túlbuzgó pánrusszok külön vajdaság, nemzeti autonómia, kongresszus mellett buzgólkodnak”. Idézi: MAYER Mária, Kárpátukrán (ruszin) politikai és társadalmi törekvések 1860-1910, Akadémiai, Budapest, 1977, 28. Az országgyủlésen azonban ezt nem tudta előadni, mert 1849-es, a cári csapatok oldalán folytatott tevékenysége, majd az abszolutizmus szolgálata miatt megsemmisítették mandátumát. Beszédét Bécsben tudta kinyomtatni.

11 MAYER: i. m., 33. KemÉNy G. Gábor némileg eltérő tartalommal ismerteti: A nemzetiségi kérdés története, 68. 
A nemzetiségi törvény szlovák szemmel

\section{Szlovákként a Natio Hungarica sáncain belül - a felföldi nemesség kettös identitása}

A felföldi, szűkebben a szlovák nyelvhatáron túli nemesi családok nyelvhasználata és identitása csak az elmúlt két-három évtizedben kapott figyelmet, mind Szlovákiában, mind Magyarországon. A „magyar úr - szlovák jobbágy” lapidáris tétele immár a múlté: a kutatások rámutatnak, hogy a főnemességnél legalább a XVIII. század derekáig, a közép- és kisnemességnél pedig legalább a XIX. század közepéig a vidék, jelesül jobbágyaik nyelve az uralkodó. Érzékeltessük mindezt néhány példával!

Štúr egy 1842-es levele megragadta a Nyitra megyei közgyủlés felpaprikázott hangulatát, a másfél ezernyi, jórészt kisnemes felháborodását „[...] minden rossz a magyarositásból ered, önök megcsaltak minket, hiszen olyan nyelven beszélnek, amelyet mi nem értünk, önöknek szlovákul kell beszélniük, mi szlovákok vagyunk, szlovák nemesek, szlovák nyelvünknek olyan értéke és súlya kell, hogy maradjon, amilyen egykoron volt neki". ${ }^{12} \mathrm{~A}$ liptói nemesek pedig 1840-ben hangzavart keltettek a számukra érthetetlen magyar beszéd alatt, ami országos hírnévre tett szert, Kossuth is nehezményezte a Pesti Hírlapban (ő még úgy tudta, hogy az egész gyűlés szlovákul zajlott). ${ }^{13} \mathrm{Az} 1861$ őszén zajlott liptói megyegyűlés nemzethű szónoka szenvedélyes kérdést intézett a jelen levő nemesivadékokhoz: e famíliák (Bogomir/ Szent Iványi, Smrečáni, Bán, Podhorný, Podhorány, Horanský, Okoličani, Matašovský, Palud'ai, Platthy, Kubinyi, Rakovský, Pongrác család és a többiek) „nem az ősi, tiszta szlovák fajból származnak? [...] És mindezek, folytatta, azelött nem szégyellték szlovák anyanyelvüket, nem mondtak le róla, nem titkolták, [...] maguk között is szivesen beszéltek, leveleztek szlovákul, sőt akadtak, akik szlovák könyveket írtak, nyomattak."14

1848-ban világossá vált, hogy ez a nemesség akár kardot is képes ragadni, mégpedig saját kormánya ellen, ha úgy érzi, az új rend (az áprilisi törvények) veszélybe sodorják vezető szerepét a megyegyüléseken. Az említett kötelező magyar nyelvű tárgyalásra kevesen voltak képesek, ezt a legtöbb helyen nyilván rugalmasan kezelték, több vármegye (Árva, Trencsén, Zólyom) viszont a latin helyett a szlovák nyelvűség engedélyezését kérte, a „vezérmegye”, a tisztán szlovák Turóc (Fényes Elek kevés német mellett magyarokat nem tudott kimutatni) viszont a kérvényezés után fellázadt, köznép és nemesség lelkesen fogadta Hurbanék önkénteseit, Kossuthnak a megyéből származó Justh Józsefet kellett kiküldenie kormánybiztosként, akinek így alkalma nyílt, hogy testközelből rálásson a magyarosítás buktatóira. ${ }^{15} \mathrm{Az}$ Októberi Diplomát kihasználva a megyeháza újfent „hallatlan” esemény színhelye lett. „Midőn 1860-ki december 20-kán az oktoberi diploma folytán Turóc megye ismét szervezkedett, és Hodzsa András evang. lelkész

12 Idézi Demmel József: Pánszlávok a kastélyban. Justh József és a szlovák nyelvü magyar nemesség elfeledett története, Kalligram Kiadó, Pozsony, 2014, 31.

13 Kosáry Domokos: A Pesti Hírlap nacionalizmusa 1841-1844, Századok 1943/75, 7-10, 396. Bővebben: DemmeL: $i . m ., 32$.

14 Opis liptovského stoličného shromaždenia dňa 23. a 24. septembra t. r., Pešt́budínske vedomosti, 5. novembra 1861. 1.

15 Az 1848-1849-es eseményeket részletesen ismerteti Deмmel: i. m., 74-107. 
inditványozta, hogy a jegyzőkönyv tótul is vezettessék, ez ellen pedig Lehoczky János felszólalt, idősb Justh József azonnal pártolta az inditványt, azt befolyásánál és tekintélyénél fogva minden további ellenmondás nélkül határozattá emelte, bátorítván az által nem csak a Túróczi panszláv elemet jövőre is, de példát szolgáltatván ez által a többi nemzetiségnek országszerte hasonló követelményekre."16 Révay Simon főispán a megyegyủlésen érzékeltette, hogy az anyanyelvűség a belső békét is szolgálja: „nehogy jövőre testvér testvér ellen, polgár polgár ellen fegyvertfogjon, igen szükséges [...] miszerint a magyarok és tótokkal [...] a haza boldogságát testvérilegfenntartsák". ${ }^{17}$ A nemesség és maga a tisztikar a Memorandum-gyülésen (1861) és a Matica megalapításánál (1863) is exponálta magát

Liptó vármegye ugyancsak áttért a szlovák tárgyalási nyelvre. A már említett megyegyülésen az egyik tekintélyes szereplő sietett kijelenteni, hogy ő is a szlovák nemzet fia, miközben magyarbarát, az országgyủlés munkáját védő fölszólalásából politikai nemzetfölfogás áradt: a nyelvért nem adja föl a szabadságot (azt fejezve ki, hogy nem a nem magyarok jogai az elsődleges tárgy). A megjelent beszámoló szerint a főispán magyar bevezető mondatai után egyetlen nem szlovák szó sem hangzott el a tárgyalás során. ${ }^{18} \mathrm{Az}$ itteni nemesség vagy egy része szlovák nyelve és identitása az évtized végén is természetesnek tűnt, 1868 őszén nemzetiek találkoztak népes nemesi társasággal, abban a megye alispánjával, aki kifejezte óhaját, hogy ezekben a megyékben a hivatali nyelv - az egyéni szabadságot nem sértve legyen a szlovák. ${ }^{19}$ A szervező irányzat lapja lelkes cikkben üdvözölte a szlovák nemesség újjászületését, egyesülését a néppel, azt, hogy belátja, nem kell a magyarok szolgájának, nyelvük alávetettjének lennie. A szerző szerint ez utóbbi téren nincs elrendelt különbség: „A magyar nyelv önmagában nem 'úri' nyelv, ez a nyelv az Alföldön ugyanúgy a köznép nyelve, mint a Felföldön a mi szlovák nemzeti nyelvünk.” A magyarok pedig nem urai a szlovákoknak, „egy hajszállal sem különbek", uralmukat a szlovákok el nem ismerik soha. A szlovák nemességnek fel kell végre emelkednie önbecsülésben, anyanyelve tiszteletében..$^{20}$

Zólyom vármegyében, ahol a polgári elem volt jelentős részben szlovák, 1861-ben szintén felvetődött a probléma. „Itt fellépett Július Plošic a szlovák hivatalos nyelvérdekében, és e kicsi, de bátor, lelkes legény beszédének nagy hatása volt, amit abból is látni lehetett, hogy maga a föispán, Anton Radvánszky úr [a forrás szlovák nyelvü, br. Radvánszky Antalról van szó - Á. B.] támadta elég élesen, de nem nyersen.” Ám annak unokatestvére ráförmedt, „hogy ez a nép lázítása, hogy bánja és bánni fogja, hogy Plošicot a bizottságba fogadta", amivel elvágta az ügyet. ${ }^{21}$

Fontos tanulságként szolgálhattak mindezek a hatvanas évek törvényhozói számára.

16 A névtelen jelentést idézi: Demmes: $i . m ., 162$.

17 Idézi: Demmel: i. m., 164.

18 Opis liptovského stoličného shromaždenia. In: Pešt'budínske vedomosti, 1. novembra 1861. 3. 8. novembra 1861. 3.

19 Közli: František BoKes (zost.), Dokumenty k slovenskému národnému hnutiu v rokoch 1848-1914, II, VSAV, Bratislava, 1965, 133-135., magyarul: Demmel József: Magyar haza, szlovák nemzet. Alkotmányos szlovák politikai törekvések Magyarországon (1860-1872), Magyarországi Szlovákok Kutatóintézete, Békéscsaba, 2016, 219-224.

20 Slovenské zemänstvo. Közölve: BoKes: i. m., 136-137, magyarul: Demmel: i. m., 191-193.

21 Idézi: Demmel József: „A nemzetiségi törvény megzavarta az elméket.” Az 1868: XLIV. törvény visszhangja a felső-magyarországi regionális politikai elitek körében = Nemzetiségek és törvényhozás Magyarországon, szerk. KovÁcs Kálmán Árpád, Országház Könyvkiadó, Budapest, 2019, 233. 
A nemzetiségi törvény szlovák szemmel

\section{A szlovák politika és a nemzetiségi törvény megszületése}

A národovec ('nemzethư') tábor erőteljesen készült az 1865-ös választásokra, jelöltjeik programja vagy az egységes Ausztria mellett szállt síkra, vagy legalábbis párhuzamos magyar-nem magyar tárgyalásokat sürgetett, melyek eredményeként minden hazai nemzetnek teljes önkormányzatot kell nyernie. ${ }^{22}$ Egyik sem jutott be, a felföldi szláv ügy képviselete megint csak Dobrjánszky Adolfra maradt (megválasztását többen most is megpróbálták érvényteleníttetni, de a bizottság ezúttal igazolta. Látványos, de nem különösebben sikeres szerepet játszott, csatlakozott a Mocsonyi-Branovácsky-Miletić-féle nemzetiségi törvényjavaslathoz, mely a hat történeti országos népség teljes egyenjogúságára alapozott, ${ }^{23}$ de a következő, meglehetősen kényes feladatot már nem oldotta meg.

Huszonhárom szepességi szlovák község, részben az ő közreműködésével, petíciót fogalmazott az országgyủlés számára, láthatólag megelégelve a Tisztelt Ház, mondhatjuk, szabotáló hozzáállását, kérelmezve, „hogy haladék nélkül térjen át a nemzetiségi kérdés tárgyalására, és oldja meg azt a jog és igazság alapján”. Ezután következik a kérvényezők szlovák vonatkozású törvénytervezete, mely követeli a szlovák nemzet egyenjogúságának elismerését, a megyék nemzetiségi alapú kikerekítését, az ottani nyelven történő igazgatását, az országos szerveknél szlovákok arányos alkalmazását, szlovák osztályok felállítását, saját nemzetgyủlések engedélyezését, az országos mellett a fehér-kék-piros lobogó szabad használatát, a szlovák tanítási nyelvet minden szinten (a gimnáziumokban a magyar nyelv legyen tantárgy!), hat állami fenntartású fö- és nyolc algimnáziumot, két fö- és hat alreáliskolát, két tanítóképzőt, mezőgazdasági és ipari iskolákat, két jogakadémiát, a pesti egyetemen rendes tanárt, a szlovák nyelv és további oktatókat minden egyéb tárgy oktatására. A nemzet lélekszámához mérten államilag támogatandók a tudományos társaságok, egyesületek. ${ }^{24}$

Dobrjánszky a petíciót taktikai okból nem terjesztette az országgyủlés elé (a pesti szlovák lapban 1868. február 7-én megjelent követelés így is tiltakozáshullámot váltott ki). Felszólalt még a törvény záró vitájában (1868. november 25.), ahol (másokhoz hasonlóan) megragadta a többségi (Deák hatására módosított, immár az egységes politikai magyar nemzet alapján álló) és a kisebbségi (nemzetiségi) javaslat lényegi különbségét: „a többségi javaslat nem abban tér el a kisebbségi javaslattól, hogy a törvényhatósági területek kikerekitését, a nyelvek bizonyos területhez kötött uralmát, és a hivatalok, méltóságok, a nemzetek közötti aránylagos megosztását el nem fogadván, az egyéni szabadság alapján kivánja megoldani a nemzetiségi kérdést, hanem abban tér el elvileg a kisebbségi javaslattól, miként hallgatással mellözvén az ország nemzeteinek tényleges s törvényes létét, az egyéni szabadságnak a nyelv használata körüli lényeges korlátozására szoritkozik, sezáltal alapját veti meg azon legújabb időben mindinkább elharapózó törekvésnek, mely egyenesen tagadásba vévén a nem-magyar nemzetek létét, egyedül a magyar nemzetet ismeri el nem csak, hanem azt, mint állitólagos politikai nemzetet igyekszik az ország népének, tehát az állam politikai

22 A választási programokat közli: BoKEs: i. m., 432-440.

23 Közli: KEMÉNY: i. m., 85-92.

24 Közli: KemÉny G., Iratok a nemzetiségi..., i. m., 75-77. 
tényezőjének helyébe állitani...”25 Úgy vélte, a nemzetiségi törekvések visszanyúlnak a Hármaskönyvig, Werbőczy úgymond felsorolja az egyenrangú hazai nemzeteket (mint későbbi felszólalók rámutattak, a nationes kifejezés valójában a jobbágyságot fedi). ${ }^{26}$ Szereplése hattyúdalaként november 29-én ott volt a tiltakozásként kivonuló 24 nemzetiségi képviselő között.

Mégsem állíthatjuk, hogy ,a szlovákok” nem hatottak a lassan-lassan születő törvényre. A szálak ismét Justh Józsefhez vezetnek. A Deák Ferenc jobb kezének tekinthető, a parlamenti frakciót vezető turóci nemes, nyilván negyvennyolcas megdöbbentő tapasztalatai hatása alatt 1867-ben, a köztörvényhatóságokról szóló miniszteri javaslat tárgyalásánál felvetette: a nem magyar vidékek törvényhatósági testületeiben bárki szabadon használhassa anyanyelvét, és ez minden valószínűség szerint meghatározta a majdani törvény megengedő rendelkezését (2-6. §), miközben a törvényhatóságok integritása nem sérülhetett. Elfogadható tehát a mai kutató megállapítása, miszerint a törvény nem a kerületet követelő szlovák nemzetiek, hanem a magyarul nem beszélő helyi nemesi eliteknek kívánt kedvezni. ${ }^{27}$

\section{A pálya szélén. A nemzeti tábor állásfoglalásai}

Habár a padsorokban nem tehették, sajtójában, röplapokon a nemzetiek számos alkalommal kifejtették nézeteiket, előbb a születő dualizmus rendszerével, majd a készülő törvénnyel kapcsolatban. A Birodalom és abban Magyarország berendezkedését illetőleg csak annyit említünk, hogy autonóm területekre épülő összbirodalmat képzeltek, legalábbis párhuzamos tárgyalásokat sürgettek a magyarság és a többi nemzet között, elítélték „, hárommilliós (!) szlovák nemzet, a magyar nemzet idősebb testvére jogtalan helyzetét”, titkos körlevélben pedig a szlovák kérdés megoldását sorsdöntő fontosságúnak minősítették a Birodalom számára, mert Magyarország második legnagyobb nemzeteként az ő jogainak biztosítása törheti meg a magyar arisztokrácia uralmát, adhatja vissza Ausztria egyensúlyát, normális működését. ${ }^{28}$

Elméleti cikkben elvetették a történeti jogra épülő területi egységek rendszerét, tehát a magyar - egyben a cseh - politikai nemzet fogalmát. ${ }^{29} \mathrm{~A}$ dualista megoldás győzelmében az utolsó pillanatig kételkedtek, sőt megszületése után sem aggódtak túlságosan, biztosak voltak abban, hogy a Monarchia pénzügyi és egyéb gondjai, valamint a szlávok és románok túlsúlya, ezután csak erősödő összetartása az új rendszert, ha egyáltalán sikerül bevezetni, gyorsan meg fogja buktatni. ${ }^{30}$

25 E részét közli: KemÉny G., Iratok a nemzetiségi..., i. m., 141-142.

26 KeмÉny G. Gábor, A nemzetiségi kérdés története..., i. m., 99.

27 Demmel, „Pánszlávok a kastélyban”..., i. m., 195., ill. Demmel, „A nemzetiségi törvény megzavarta..., i. m., 235.

28 A választási programok kiadását lásd 20. lábjegyzet, Daxner körlevelét lásd uo., 443-446.

29 Foederalismus, Peštbudínske vedomosti, 7. septembra 1866. 1.

30 Andrej ČERVENÁK: Program Slovenska [1866. közepe] = Dokumentyk slovenskému národnému hnutiu v rokoch 1848-1914, II, szerk. František BokEs, VSAV, Bratislava, 1965, 14. Az első, magabiztos reakció: Pešt'budinske vedomosti, 4. januára 1867. 1. 
A nemzetiségi törvény szlovák szemmel

A kiegyezési tárgyalások kapcsán - melyek 1866 őszén látszólag kátyúba jutottak - a pesti lap figyelmeztetett, hogy a magyar pártok a kudarc ódiumát a nemzeti egyenjogúságot óhajtó nemzetiségiekre fogják hárítani, amit a nemzeti tábor nevében elutasított. $^{31}$

A nemzetiségi kérdés - szó szerint vett - állásáról a pesti lap többször kemény kritikát mondott, leghatározottabban 1867. május 24-én megjelent cikkében. Eszerint, míg a bajban a magyarok ígértek sok mindent, most, a kiegyezés óta „az országban minden befolyás, minden elöny az alkotmányosság és szabadság élvezetének minden elöfeltétele - mint egy ellenség által meghóditott és leigázott országban - a 'Deák-klub' hiveire szállott, és a nem-magyarokat hol furfanggal, hol erőszakkal, de 'minden áron' kirekesztették. A nemzetiségi kérdésben kiküldött országgyülési bizottság - füle botját sem mozgatja; mintha az országgyülésnek érzéke sem volna a nemzetiségi kérdés iránt; a minisztérium ugyan az egyik törvényjavaslatot terjeszti be a másik után, de a nemzetiségi kérdésről szó sincs.” Márpedig a nem magyar népek, így a szlovákok „az életnek és a szabad nemzeti fejlődésnek tartós és minden körülmények között biztos jogát el akarják érni és így azt kivánják, hogy [...] országos és a trón által elismert, tehát országos törvénnyel és koronázási diplomával megerösitett és biztositott jog legyen. [...] Mivel Ő felsége koronázására a törvényhozás és a politikai előkészületek már a tárgyalás fokán vannak: tisztelettel kérjük az országgyülést és a magas kormányt:félreérthetetlenül hasson oda, hogy a nemzetek - és közöttük a szlovák nemzet - nemzeti életének és szabad fejlödésének biztositása érdekében még a koronázás előtt országos törvény hozassék, s hogy ezt a törvényt koronázási oklevéllel biztositsák. Mint az ország mintegy három millió szabad polgárának független szócsöve, e kivánság kifejezésére feljogositottnak érezzük magunkat, ugyanakkor azonban kötelességünknek érezzük ezt magával az országgal szemben is, mert nagyon nem tartjuk tanácsosnak az idő indokolatlan elhúzásával s a menthetetlen tologatással az emberi eröt és gyarlóságot kisértésbe vinni s kihivni a változhatatlan és kérlelhetetlen lelki és természeti törvények önnön maguktól növö következményeit." ${ }^{2}$

A nemzeti tábor másik irányzata 1868-ban megfogalmazta a maga törvényjavaslatát (arra hivatkozva, hogy a kiküldött bizottság három év alatt nem tette le a magáét az asztalra), melyet szinte egészében bármely nemzethủ gondolkodó aláírhatott volna. Kezdő mondatai: „A Magyarországon élő szlovák nemzet politikai, állampolgári és társadalmi tekintetben teljesen egyenjogú a magyar és a többi nemzettel. Magyarország minden nemzete egy egységet alkot, amelynek részei a következö nemzetek: szlovák, magyar, horvát, szerb, ruszin és román. ${ }^{33}$ A tervezet az eddig megszokott széles körü nyelvi jogokat követeli. Mi hiányzik? A területi autonómia, a Kerület követelménye.

31 Štefan Marko Daxner: Pred snemom (Az országgyűlés előtt), Pešttbudínske vedomosti, 20. novembra 1866, 1.

32 Úctivá ale súrná žiadost' (Tiszteletteljes, de sürgős kívánság), Pešt'budínske vedomosti, 24. mája 1867, 1. Magyarul közli: KemÉny G. Gábor: Iratok I., 24-26.

33 Közli: DemmeL: Magyar haza..., i. m., 216-219. 


\section{Szlovák politikák kora}

A szlovák eredményes fellépést, érdekérvényesítést nem csak nehezítette, hanem gyakorlatilag lehetetlenné tette a politizáló elit megosztottsága. ${ }^{34}$ Nem kanyarodunk vissza a nemességhez, láttuk, hogy akár hangsúlyozott szlováktudata mögött is mindig ott rejlik a megyei pozícióőrzés parancsa. Meddig lehetett ezt összeegyeztetni? Annyi bizonyos, hogy az említett megyékben évtizedekig gyakorlat maradhatott a szlovák, illetve vegyes tárgyalási nyelv, az ismert, hogy Zólyom megyében 1886-ban vált egyeduralkodóvá a magyar. ${ }^{35}$

Újabb megosztó tényezőként, a kultuszminisztérium kiadásában jelent meg Pesten, 1864-68 között a Krajan, mely programcikkét olvasva ugyanolyan elkötelezett nemzeti orgánumnak tűnhetett, mint a Vedomosti. Rámutatott, hogy a szlovák sajtó a legutolsó a hazában, a műveltek magyart, németet olvasnak, a nép pedig írástudatlan. Politikai alapjaként a trón és a nemzet egységét vallotta, az „igaz hazafiság” parancsát, hangsúlyozva: a felgyorsult európai fejlődés új törvényeket, gazdálkodást követel, a haza fiai azonban egymás ellen harcolunk, pedig a régi nemzetek bukását is a széthúzás okozta. Szűnjék meg tehát a nemzetiségi, nyelvi villongás! - figyelmeztetett a Felső-Magyarhonban terjedő, úgymond széthúzást, gyủlöletet szító eszmékre (tehát a Vedomosti eszmeiségére). ${ }^{36}$

A támadott nemzeti lap viszont a Krajant a renegátok eszközének tekintette, azon párt szócsövének, „mely magát szlováknak vallja, a szlovák nemzethez számitja magát, sőt, mi több, magát tekinti az igazi szlovákságnak, minket pedig, akik a nemzeti eszme ébredése óta kiálltunk, dolgoztunk és szenvedtünk a szlovák nemzetért, 'pánszlávoknak'nevez.” Ám legyen, csak dolgozzon a nemzet érdekében, amire jobbak a feltételei: tábora ül a vezető pozíciókban, köztük gr. Forgách Antal kancellár és gr. Pálffy Móric helytartó (úgymond mindketten vallották már magukat szlováknak). Ám a Vedomosti szerint e tábor csak rombol, mint azt a besztercebányai gimnázium elleni támadás is jelzi. A nemzeti felelősség kérdése tehát: „Ti minket, 'pánszlávokat' eröszakkal, fortéllyal megfosztottatok attól, hogy hathassunk a törvényhozásra, részt vehessünk a kormányban, az ország és a megyék irányításában. Egyedül nektek van meg a lehetöségetek, hogy tegyetek valamit a szlovák nemzetért, ám egyben rátok, jelen körülmények között, ilyen idöszakban jóformán egyedül rátok háramlik a felelösség azért, hogy mi történik és nem történik a szlovák nemzet érdekében." ${ }^{37}$

A Krajan szerkesztősége maga is közzétett egy nemzetiségi törvénytervezetet, mely a többihez hasonló, mai szemmel széles körủ egyéni nyelvhasználati jogokat irányoz elő, ám kollektív szervezetekről (nemzeti alapú önkormányzat, saját nemzetgyủlés, irányító testület) természetesen nem beszél. ${ }^{38}$

Sokkal megosztóbbnak bizonyult a vitán felül nemzetileg elkötelezett Új Szlovák Iskola, melynek gyökerei a Memorandum-gyülésre nyúlnak vissza, s mely azon személyek

34 A hatvanas évek belső csatározásait a sajtóorgánumokon keresztül vázolom: Szlovák sajtó és nemzetépités a dualizmus korában = A sajtó kultúraközvetitő szerepe 1867-1945, szerk. PAÁL Vince, MTA BTK, Budapest, 2014, 51-67.

35 Demmel: A nemzetiségi törvény..., i. m., 237-239.

36 Naše politickuo viznaňja, Krajan, 3. marc. 1864, 1.

37 Panslávi a „Krajani” ('Pánszlávok és 'földik”), Peštbudínske vedomosti, 21. júnia 1867, 2. 25. júnia 1867, 2.

38 Közli: Bokes: Dokumenty II..., i. m., 143-144. 
körül alakult ki, akik 1861-ben vagy utána mint irreális követelést elutasították a Szlovák Kerület gondolatát. Gazdag pesti gyárosokra támaszkodva 1868-ban az ambíciózus pesti építész, Ján Nepomuk Bobula megindította a Slovenskénovinyt. Programcikke a nemzeti önállóság jelszavát hirdette, ám nem említette a Szlovák Kerületet, annál inkább az ország integritásának védelmét s a magyar-szlovák sorsközösséget, amely mindenféle külső beavatkozás nélkül, a teljes egyenjogúság alapján a nemzet jövőjének záloga. A két nép egyenjogúsága, barátsága Magyarhon egységének alapja: a nagyromán, nagyszerb aspirációkkal szemben a szlovákoknak nincs hova gravitálniuk. Ha elnyerik nemzeti jogaikat, az államegység legelszántabb őrei lesznek. A szlovák sajtó jelentőségét az adja, hogy az urak átmentek a magyarok táborába, a polgárság közömbös, a nép sötétségben alszik. A fő bűnös a polgárság, a lap úgymond elsőként azt akarja megnevelni, majd a népet fölrázni. Kijelentette, hogy nem adta el magát, nem a Deák-párt kegyén él, mint a Krajan. A Vedomostiról úgymond köztudott, hogy pánszláv lap, minden igaz „szlovák és uhor" a Slovenské novinyt olvassa! ${ }^{39}$ Nevesítés nélkül találkoztunk már e csoporttal a liptói nemesekkel folytatott megbeszélés, a szlovák nemesség értékelése kapcsán, és olvastuk törvényjavaslatukat (33. lábjegyzet).

A két pesti hírlap között azonnal gyilkos, személyeskedésekkel tủzdelt konkurenciaharc indult meg. A Vedomosti azzal vádolta vetélytársát, hogy a kormány instrukciójára jött létre, míg Bobula a Vedomostit pánszláv, orosz, hazaáruló lapnak nevezte, néhányadmagával kilépett a Szlovák Egyesületből és megalapította a Szlovák Nemzeti-Demokrata Egyesületet, amely később tehát Új Szlovák Iskolaként vonult be a köztudatba. Bobuláék számítottak a magyar politikusokkal való megegyezésre, kezdetben a szélsőbalos ellenzékben (Szilágyi Virgil, Madarász József) találtak szövetségesre, ${ }^{40}$ később már a kormányzó Deák-párttól fogadtak el szubvenciót. A magyar politika merevsége s a két lap polémiája miatt népszerűségük egyformán csökkent, elvetélt fúziós tárgyalásokat folytattak, végül is a Vedomosti 1870-ben átköltözött Turócszentmártonba, s nevet is változtatott. A Slovenské noviny viszont - politikájának csődje, az Új Iskola fölbomlása nyomán - 1875-ben megszủnt.

\section{$\overline{\text { 7. Az elsö tapasztalatok }}$}

Immár csak felvillantva, kérdezzünk rá, milyen tapasztalatokat szerezhetett a nemzeti szlovák elit a törvény elfogadása körüli időszakban? A mindennapok szintjén, az egyén nyelvhasználatában minden bizonnyal érvényesült az anyanyelv használata, ezt akár két bizarr példával is érzékeltethetjük. Báró Radvánszky Antalt országos evangélikus

39 Naše politické stanovisko, Slovenské noviny, 2. jan. 1868. 1.

40 A Magyar Újság közölte a Slovenské Noviny hozzá írott nyílt levelét. Kiderül, hogy a Magyar Újságot a Pesti Napló és az Ungarischer Lloyd (a Deák-párt szócsövei) támadja, amiért baráti viszonyt tart fönn ezzel a ,derék tót lappal”. ,Minthogy pedig a Magyar Újság azon egyetlen egy lap, mely a magyar nemzetnek - melynek a Pesti Naplóék csak igen picike töredéke - rokon érzelmeit tolmácsolja, és az annyira áhitott nemzeti egyenjogúságot hirdeti, a Pesti Napló kikiáltotta e lap szerkesztőjét pánszlávnak." Idézi KeмÉny G. Gábor (szerk.): A szomszéd népekkel való kapcsolataink történetéböl. Válogatás hét évszázad írásaiból, Budapest, Tankönyvkiadó, 1962, 540-541. 


\section{ERDÉLYI JOGÉLET}

főfelügyelői ténykedései (a „pánszlávizmus” elleni harc) miatt a nemzetiek közellenségnek tekintették, ám 1874-es köszöntő ünnepségén szlovák szónoklatra is szükség volt, mert ebben a nemzeti törekvésekkel oly ellenséges megyében sok bizottmányi tag nem bírta az állam nyelvét. Az ekkor alispán Grünwald Béla, a szlovák gimnáziumok és a Matica „gyilkosa”, 1880-ban szlovák hirdetményben tájékoztatta választóit a Szabadelvű Pártból történt kilépéséről. ${ }^{41}$

Intézményépítést viszont a hatalmi körök már nem tettek lehetővé, mint azt baljósan előre vetítette a gimnáziumalapítási terv sorsa. 1872-ben Jozef Kajuch (mérsékelt) képviselő kérelmezte, hogy az állam a nemzetiségi törvénynek megfelelően állítson fel szlovák tannyelvü gimnáziumokat. Nem légüres térben mozgott, a bomló Deák-pártnak ugyanis szüksége volt a nemzetiségi régiók szavazataira, az Új Szlovák Iskola is kampányolt mellette, ám a kormány bukása és az ellenző hangok erősödése (maga Trefort Ágoston is) miatt az akció elhalt. ${ }^{42} \mathrm{~A}$ következő év pedig már a három gimnázium bezárását hozta magával, amit 1875-ben a Matica megszüntetése követett.

\section{Irodalomjegyzék}

1. 1-ső melléklet a 133. sz. irományhoz = Az 1865-dik évi december 10-dikére hirdetett országgyülés képviselőházának irományai II, Pest, 1867.

2. ÁвRAнÁм Barna: Szlovák sajtó és nemzetépités a dualizmus korában = A sajtó kultúraközvetitő szerepe 1867-1945, szerk. PAÁl Vince, MTA BTK, Budapest, 2014.

3. ÁвRAнÁm Barna (összeállította és a bevezetőt írta): Magyarságkép a XIX-XX. századi szlovák irodalomban (szemelvénygyưjtemény), Magyar Napló, 2006/11.

4. Balogh Sándor (főszerk.), Sipos Levente (szerk.): A magyar állam és a nemzetiségek. A magyarországi nemzetiségi kérdés történetének jogforrásai 1848-1993, Napvilág Kiadó, Budapest, 2002.

5. BokEs, František (zost.): Dokumentyk slovenskému národnému hnutiu v rokoch 1848-1914, I, VSAV, Bratislava, 1962.

6. BoKes, František (zost.): Dokumenty k slovenskému národnému hnutiu v rokoch 1848-1914, II, VSAV, Bratislava, 1965.

7. Demmel József: Magyar haza, szlovák nemzet. Alkotmányos szlovák politikai törekvések Magyarországon (1860-1872), Magyarországi Szlovákok Kutatóintézete, Békéscsaba, 2016.

8. Demmel József: „A nemzetiségi törvény megzavarta az elméket.” Az 1868: XLIV. törvény visszhangja a felsô-magyarországi regionális politikai elitek körében = Nemzetiségek és törvényhozás Magyarországon, szerk. Kovács Kálmán Árpád, Országház Könyvkiadó, Budapest, 2019.

9. Demmel József: Pánszlávok a kastélyban. Justh József és a szlovák nyelvü magyar nemesség elfeledett története, Kalligram Kiadó, Pozsony, 2014.

41 Demmel: A nemzetiségi törvény..., i. m., 238-239.

42 VesZTRóczy Zsolt: A nemzetiségi törvény, mint potenciális veszélyforrás? Grünwald Béla alternativ nemzetiségpolitikai elképzelései az 1870-es években = Nemzetiségek és törvényhozás Magyarországon, szerk. Kovács Kálmán Árpád, Országház Könyvkiadó, Budapest, 2019, 153-155. 
10. HaVRáNeK, Jan: Nemzeti és birodalmi eszmények vonzásában (František Palacký - a politikus és kora) = Csehország a Habsburg-monarchiában 1618-1918, szerk. SzARKA László, Gondolat Kiadó, Budapest, 1989.

11. KemÉny G. Gábor (összegyüjtötte): Iratok a nemzetiségi kérdés történetéhez Magyarországon a dualizmus korában I, Tankönyvkiadó, Budapest, 1952.

12. KemÉny G. Gábor: A nemzetiségi kérdés története. I. A nemzetiségi kérdés a törvények és tervezetek tükrében 1790-1918, Budapest, 1947.

13. KemÉny G. Gábor: A szomszéd népekkel való kapcsolataink történetéből. Válogatás hét évszázad irásaiból, Tankönyvkiadó, Budapest, 1962.

14. Kosáry Domokos: A Pesti Hírlap nacionalizmusa 1841-1844, Századok 75, 1943.

15. MAYer Mária: Kárpátukrán (ruszin) politikai és társadalmi törekvések 1860-1910, Akadémiai, Budapest, 1977.

16. Minač, Vladimír: Összefüggések, Madách Könyvkiadó, Bratislava, 1980.

17. SPIRA György: A nemzetiségi kérdés a negyvennyolcas forradalom Magyarországán, Kossuth Könyvkiadó, Budapest, 1980.

18. VeSZTRóczy Zsolt: A nemzetiségi törvény, mint potenciális veszélyforrás? Grünwald Béla alternativ nemzetiségpolitikai elképzelései az 1870-es években = Nemzetiségek és törvényhozás Magyarországon, szerk. Kovács Kálmán Árpád, Országház Könyvkiadó, Budapest, 2019. 